\title{
Mutational Analysis of Plasmodium vivax dhfr Gene Among Cases in South East of Iran
}

\author{
Hadi Mirahmadi, ${ }^{1,2}$ Maryam Rafee, ${ }^{2}$ Jalal Zaman, ${ }^{3}$ Ahmad Mehravaran, ${ }^{1,2}$ and Reza Shafiei ${ }^{4, *}$ \\ ${ }^{1}$ Infectious Diseases and Tropical Medicine Research Center, Zahedan University of Medical Sciences, Zahedan, Iran \\ ${ }^{2}$ Department of Parasitology and Mycology, Faculty of Medicine, Zahedan University of Medical Sciences, Zahedan, Iran \\ ${ }^{3}$ Orumiyeh military Hospital, Health Administration of Army (NEZAJA), Tehran, Iran \\ ${ }^{4}$ Vector-borne Diseases Research Center, North Khorasan University of Medical Sciences, Bojnurd, Iran \\ "Corresponding author: Reza Shafiei, PhD., Vector-borne Diseases Research Center, North Khorasan University of Medical Sciences, Bojnurd, Iran. Tel: +98-9157029331, E-mail: \\ reza_shafi@yahoo.com
}

Received 2017 February 26; Revised 2017 July 26; Accepted 2017 August 06.

\begin{abstract}
Background: Plasmodium vivax and P. falciparum have been detected in south east of Iran. Plasmodium vivax has a higher prevalence in this area. Point mutation in P. vivax dihydrofolate reductase ( $p v d h f r$ ) gene is the key mechanism of Sulfadoxine and Pyrimethamine (SP) resistance.

Objectives: This study aimed at investigating pvdhfr mutations and haplotypes in Sistan and Baluchestan endemic province of Iran. Methods: Seventy-five blood samples from Sistan and Baluchistan province of Iran, infected with P. vivax, between years 2013 and 2015, were enrolled in this study. The samples were examined for probable point mutations in pvdhfr gene using Polymerase Chain Reaction-Restriction Fragment Length Polymorphism (PCR-RFLP) and sequencing methods.

Results: Most of the isolates (59\%) had wild type codons at 4 locations of pvdhfr gene. The F57S58T61N117 was the most common haplotype among the mutant cases (24.3\%); in these cases, the haplotypes with triple and quadruple mutations in $57,58,61$, and 117 codons were not identified. In addition, haplotypes with double mutations at location FRTN (7.7\%) and FRTT (2.6\%) were identified in studied cases.

Conclusions: This study showed that the presence of mutant $p v d h f r$ haplotypes, which are resistant to the SP is increasing, therefore, performing a molecular surveillance via the PCR method in endemic areas is very important.
\end{abstract}

Keywords: Drug resistance, Sistan and Baluchistan, Iran, Plasmodium vivax, dhfr Gene

\section{Background}

Plasmodium vivax is a protozoan parasite, which is most widely distributed around the world and responsible for more than 80 million malaria cases per year (1-3). Although the P. falciparum has a higher rate of mortality, P. vivax also accounts for remarkable morbidity and economic determinants in endemic regions (4-7). Plasmodium vivax is the most prevalent cause of malaria in different regions of Iran (8). This parasite is sensitive to most of the anti-malarial drugs, such as Chloroquine (CQ), which is applied as the first line treatment in the majority of countries $(9,10)$. Although CQ resistance has been reported in other regions of the world (11), CQ is still an efficient drug for the treatment of $P$. vivax single infections in south and southeast of Iran. It has been shown that due to multiple infections, there are primary signs of decreased sensitivity of $P$. vivax to CQ in Sistan and Baluchestan province (12).

Nowadays, regarding the worldwide extent of CQ resistance to $P$. falciparum, a combination of sulfadoxine and Pyrimethamine (SP) is used as the first-line antimalarial therapy in some countries (9). It has been shown that there is a considerable increase of CQ and SP resistance in $P$. vi$\operatorname{vax}(11,13,14)$. Therefore, according to the increase of drug resistance in $P$. vivax, elimination of this species is further complicated (15). The SP consumption for the P. vivax treatment is unusual in the majority of malarious areas, in spite of the fact that, P. vivax isolates are exposed to SP, owing to mixed infections (P. falciparum and $P$. vivax) $(16,17)$. There are a remarkable number of cases with mixed infections in endemic regions of Iran (17); therefore, SP consumption to treat $P$. falciparum leads to drug resistance in $P$. vivax cases in these regions $(12,18)$.

It has been shown that specific point mutations in dihydrofolate reductase ( $d h f r$ ) and dihydropteroate synthase (dhps) genes are correlated with SP resistance $(16,19)$. In this regard, studies have shown that mutations at pvdhfr residues 57, 58, 61, 117, and 173 were correlated with antifolate resistance $(16,20)$. Moreover, more than 20 different $p v d h f r$ alleles have been described (21). Previous studies have shown mutations of the $p v d h f r$ gene in south and southeast of Iran $(12,16)$. However, there is a lack of complete data on pvdhfr genotypes among Iranian cases, especially in endemic provinces and neighboring countries. 


\section{Objectives}

The aim of this study was to investigate pvdhfr mutations and haplotypes in Sistan and Baluchistan endemic province of Iran.

\section{Methods}

\subsection{Ethics Statement}

The protocol of this study was reviewed and approved by the ethical and research committee of Zahedan University of Medical Sciences (Code: 7216). All cases had filled informed consent forms. All procedures performed in studies involving human participants were in accordance with the ethical standards of the institutional and/or national research committee and with the 2000 Helsinki declaration and its later amendments or comparable ethical standards.

3.2. Study area, Sample Collection, and Polymerase Chain Reaction Amplification

The Sistan and Baluchistan province is one of the 31 provinces of Iran. It is located in the southeast of Iran, bordering Pakistan and Afghanistan with geographical coordinates between $29.4924^{\circ} \mathrm{N}$ and $60.8669^{\circ} \mathrm{E}$ (Figure 1). The capital is Zahedan and the most prominent climatologically phenomenon of the region is heated with long, hot and dry summers and short winters, whereas, in the coastal region, near the Oman Sea, the weather is warm with a high percentage of humidity. These conditions are suitable for the transmission of malaria in this area. Blood samples were obtained from a total of 78 symptomatic patients with $P$. vivax infection in Sistan and Baluchistan province between years 2013 and 2015. Five milliliters of venous blood was taken in EDTA tubes and stored at $20^{\circ} \mathrm{C}$. Blood films that were ready in field laboratories were rechecked. DNA was extracted by Q1Amp ${ }^{\circledR}$ DNA blood kit (Qiagen, US), according to the manufactures' instructions. Detection of point mutations at codons number 57, 58, 61, and 117 were performed as described previously $(12,16)$.

\subsection{In Silico-RFLP, PCR Amplification, and RFLP for 57, 58, 61, and 117 Positions}

Detection of enzymatic digestion sites and produced fragments were done using the CLC DNA workbench software (version 1.0.1). Fragments of the pvdhfr gene (X98123) were digested with XmnI, PvuII (611 bp), BsrI (611 bp), Tsp45I (232 bp), and Alu I (238 bp) enzymes (Fermentase, Lithuania). These enzymes recognize F57L/I, S117N/T, T61M, and S58R residues in the pvdhfr gene. In order to detect mutations at 57,117, 58, and 61 codons, the $P v d h f r$ gene was amplified by primer sequences $(12,16)$ (Table 1$)$. Thermal profile for the PCR amplification was as follow: $94^{\circ} \mathrm{C}$ for 7 minutes; 35 cycles at $94^{\circ} \mathrm{C}$ for 50 seconds, $66^{\circ} \mathrm{C}$ for 50 seconds, $72^{\circ} \mathrm{C}$ for 65 seconds and a final extension at $72^{\circ} \mathrm{C}$ for 7 minutes. In order to detect the mutation at codon F57L/I, $10 \mu \mathrm{L}$ of PCR products (608 bp) were digested with $10 \mathrm{U} \mathrm{XmnI} \mathrm{enzyme}$ (Fermentase, Lithuania). In the case of S58R, $10 \mu \mathrm{L}$ of PCR products (238 bp) were digested with $10 \mathrm{U}$ AluI enzyme (Fermentase, Lithuania) for 15 hours at $37^{\circ} \mathrm{C}$ in a final volume of $20 \mu \mathrm{L}$. For the S117N/T, $10 \mu \mathrm{L}$ of PCR products (608 bp) were digested with $10 \mathrm{U}$ PvulI enzyme (Fermentase, Lithuania) for 5 hours at $37^{\circ} \mathrm{C}$, and if there was a mutation in this codon (lack of cutting with PvuII), $10 \mu \mathrm{L}$ of the mutant Pvd$h f r$ gene PCR product was digested with $10 \mathrm{U}$ BsrI enzyme (Fermentase, Lithuania) for 15 hours at $65^{\circ} \mathrm{C}$ in a final volume of $20 \mu \mathrm{L}$. In order to detect the mutation at codon T61M, $10 \mu$ L of PCR products (232 bp) was digested with 10 U Tsp 451 enzyme (Fermentase, Lithuania) for 16 hours at $37^{\circ} \mathrm{C}$ in a final volume of $20 \mu \mathrm{L}$. The DNA fragments derived from PCR or RFLP were electrophoresed on $2 \%$ agarose gel $(12,16)$.

\subsection{DNA Sequencing and Phylogenetic Analysis}

The pvdhps gene was amplified by nested PCR, as described previously (16). Some of the nested-PCR products were sequenced directly without cloning. To enter the DNA sequence for all samples, for adjustment of the sequence and nucleotides match up with chromatography to determine the similarity of each sample with other samples, the software Sequencher Tm 4.1.1 software (Gene Codes Corporation) was used. Phylogenetic analysis was also used by the MEGA6 software.

\section{Results}

\subsection{The Frequency of Pvdhfr Gene Mutation}

A total of 78 cases from Sistan and Baluchistan Province were analyzed for SNP/haplotype and appearance of mutation in 57, 58,61, and 117 codons of the Pvdhfr gene using the PCR-RFLP method (Figure 2). All the isolates were examined for SNP/haplotype and the existence of the mutation in F57L/I, S58R, T61M, and S117N/T positions of the pvdhfr gene was determined using the PCR-RFLP method. All the products (232 bp) were digested with Tsp 45I enzyme (T61 $=171 \mathrm{bp}+61 \mathrm{bp}$ ), indicating the lack of mutation in T61M in the endemic provinces isolates. In the case of F57L/I, $2(2.5 \%)$ cases showed mutation; PCR products containing mutation were not digested by the XmnI enzyme, indicating F57L/I mutation ( $611 \mathrm{bp}=445 \mathrm{bp}+166 \mathrm{bp}$ ). Sequencing showed that the mutated cases were F57I (Figure 2 and Table 2). Ten (12.8\%) of the cases had shown the mutation in 58 codons. The PCR products containing S58R mutation were 


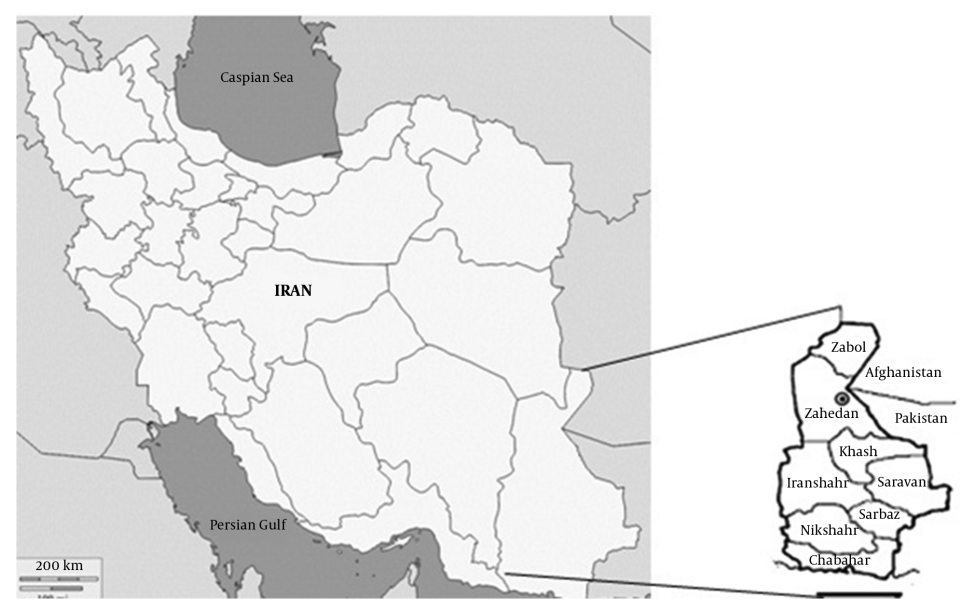

Figure 1. Map of Sistan and Baluchistan Province, Iran; Districts and Geographical Outlines Are Depicted

Table 1. The Name and Sequences of the Primers for PCR

\begin{tabular}{l|c|c}
\hline \multirow{2}{*}{ Position } & Name & Sequence \\
\hline \multirow{2}{*}{57 and 117 } & VDT-OF & 5'-ATGGAGGACCTTTCAGATGTATTT $\neg$ GACATT-3' \\
\cline { 2 - 3 } & VDT-NR & 5'-TCACACGGGTAGGCGCCGTT $\neg$ GATCCTCGTG-3' \\
\hline \multirow{2}{*}{$\mathbf{5 8 \text { and } 6 1}$} & VDF-NF58 & 5'-GACCTTTCAGATGTATTTGACATTTACGGC-3' \\
\cline { 2 - 3 } & VDF-NR58 & 5'-GGTACCTCTCCCTCTTCCACTT $\neg$ TAGCTTCT-3' \\
\hline
\end{tabular}

digested to 2 bands (three bands indicating a lack of mutation) by the AluI enzyme ( $S 58=173 \mathrm{bp}+40 \mathrm{bp}+25 \mathrm{bp}$ and $58 \mathrm{R}=213 \mathrm{bp}+25 \mathrm{bp}$ ) (Figure 2 and Table 2). The S117N/T mutation was identified in 35.8\% (28 cases) of cases. The PCR products (611 bp), which were digested by PvulI enzyme, indicated the lack of mutation in this codon (S117 $=350 \mathrm{bp}+$ $261 \mathrm{bp}$ )(Figure 2 and Table 2). The PCR products containing the mutation at codon $117(117 \mathrm{~N} / \mathrm{T})$ were digested using the BsrI enzyme, in which S117N mutation displayed 3 bands, including $117 \mathrm{~N}=290 \mathrm{bp}+253 \mathrm{bp}+68 \mathrm{bp}$, whereas, the S117T genotype was not digested (Figure 2 and Table 2).

\subsection{Distribution of Pvdhfr Gene Haplotypes}

Seven different haplotypes of the $p v d h f r$ gene were detected. The most prevalent wild haplotype was FSTS. The haplotypes with a single point mutation in 57I, 58R, 117N, and 117T forming the ISTS, FRTS, FSTN, and FSTT haplotypes, respectively, were also identified in the province. Moreover, haplotypes with double mutations at positions FRTN and FRTT were identified among the studied cases (Table 3 ). Haplotypes with 3 and 4 point mutations were not identified from Sistan and Baluchistan province.
Table 2. Distribution of Mutations in the dhfr Gene in P. vivax Isolates from Sistan and Baluchestan Province of Iran

\begin{tabular}{|c|c|c|c|c|c|}
\hline Isolate & \multicolumn{4}{|c|}{ Codon } & No. (\%) \\
\hline \multirow{8}{*}{78} & 57 & 58 & 61 & 117 & \\
\hline & $\mathrm{F}$ & $\mathrm{R}$ & $\mathrm{T}$ & $\mathrm{T}$ & $2(2.5)$ \\
\hline & $\mathrm{F}$ & $S$ & $\mathrm{~T}$ & $S$ & $46(58.9)$ \\
\hline & F & $S$ & $\mathrm{~T}$ & $\mathrm{~N}$ & $19(24.3)$ \\
\hline & I & $S$ & $\mathrm{~T}$ & S & $2(2.5)$ \\
\hline & $\mathrm{F}$ & $\mathrm{R}$ & $\mathrm{T}$ & $\mathrm{N}$ & $6(7.6)$ \\
\hline & $\mathrm{F}$ & $\mathrm{R}$ & $\mathrm{T}$ & $S$ & $2(2.5)$ \\
\hline & $\mathrm{F}$ & $S$ & $\mathrm{~T}$ & $\mathrm{~T}$ & $1(1.2)$ \\
\hline
\end{tabular}

4.3. Sequence Analysis of pvdhfr Gene in 611 bp Fragment and Phylogenetic Analysis

Sequencing was performed by Bioneer company (Korea) and registered in GenBank (accession numbers: MF381738 to MF381741). The main haplotype sequence of these genes, including the ISTS (L-VDT-OF), FSTN (PVDT-OF), (Q-VDT-OF) FRTN, and FRTT (N-VDT-OF) were compared and mutations were confirmed and directly 

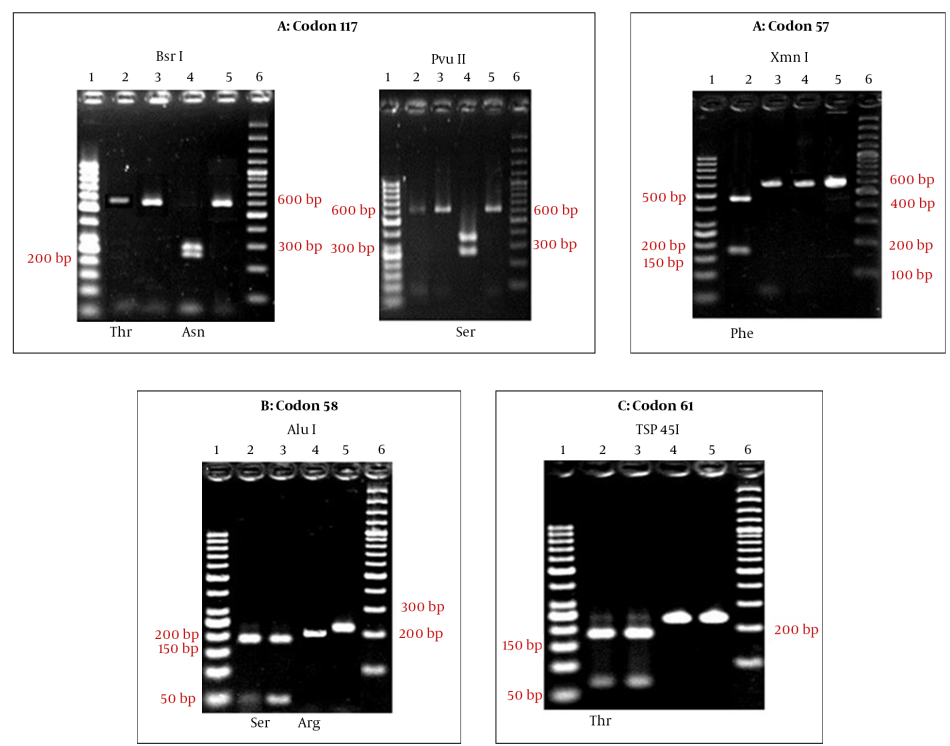

Figure 2. Restriction Fragment Length Polymorphism Patterns of the dhfr Gene for Detection of Mutation at Codons 117, 57, 58, and 61 Among the Isolates from Sistan and Baluchestan Province of Iran

Table 3. Frequency of pvdhfr Alleles Based on Variations in Codons 117, 57, 58, and 61 Among the Isolates from Sistan and Baluchestan Province of Iran

\begin{tabular}{c|c|c|c|c}
\hline $\mathbf{F} \mathbf{5 7} \mathbf{I} / \mathbf{L}$ & $\mathbf{S} \mathbf{5 8} \mathbf{R}$ & $\mathbf{T ~ 6 1 ~ M}$ & $\mathbf{S ~ 1 1 7 ~ N / T}$ & No. (\%), $\mathbf{~} \mathbf{7 8}$ \\
\hline I & S & T & S & $2(2.6)$ \\
\hline F & S & T & T & $1(1.3)$ \\
\hline F & R & T & T & $2(2.6)$ \\
\hline F & R & T & S & $2(2.6)$ \\
\hline F & R & T & N & $6(7.7)$ \\
\hline F & S & T & N & $19(24.3)$ \\
\hline F & S & T & S & $46(59)$ \\
\hline
\end{tabular}

analyzed using ABI PRISMTM 310 automated sequencer to determine $p v d h f r$ variation (haplotype) (Figure 3). Iranian pvdhfr phylogenetic tree was obtained based on bootstrap neighbor-joining method (MEGA6) in comparison with the recorded previous Iranian cases in GenBank (Figure 4).

\section{Discussion}

The present study indicated that in P. vivax isolates from Sistan and Baluchistan province, the $p v d h f r$ gene was exposed to drug pressure due to SP. In these Iranian endemic areas, CQ is still used for P. vivax treatment. Attempts to control malaria are significantly challenged due to antimalarial drug resistance in endemic regions. For this reason, there is a necessity for annual monitoring of antimalarial drug usefulness and drug resistance in endemic regions (22). In the south provinces of Iran, such as Sistan and Baluchistan, however, CQ still remains efficient against the P. vivax malaria disease. An in vivo study demonstrates that $P$. vivax clearance time is increased in Sistan and Baluchistan province (23). This process could be a primary indication of decreased sensitivity of the P. vivax to CQ. Although anti-folates were consumed for the P.falciparum treatment, insufficient data was available regarding the source and increase of this drug resistance in $P$. vivax, especially in endemic provinces of Iran.

It has been shown that investigation of allelic variation will be useful at flanking microsatellite loci of the pvdhfr gene for comprehension of the basis and extension of anti-folate resistance in $P$. vivax isolates (24). Zakeri et al. previously reported 5 different haplotypes of the $p v d$ $h f r$ gene (16). In this study, 7 different haplotypes were identified. In addition, new haplotypes of ISTS and FRTT were detected. According to previous studies, the most prevalent non-mutated haplotype was FSTS among Sistan and Baluchistan cases. The wild-type $p v d h f r$ haplotype was present with a high percentage of $P$. vivax populations from this province. This was similar to reports from malaria endemic regions in Afghanistan (25) and Pakistan (26). In this study, the frequency of mutation in codon 58 (12.8\%) and 117 (35.8\%) was similar to the author's previous study (12). In this regard, several studies have shown that the frequency of $117 \mathrm{~N}$ mutation among the isolates collected from Azer- 
A
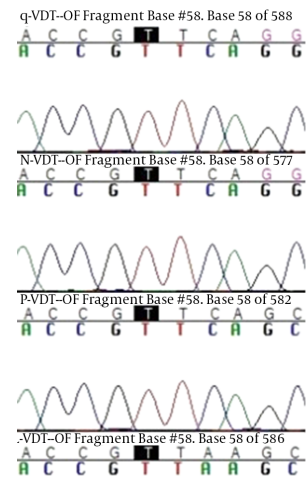

B

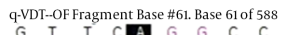

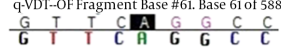
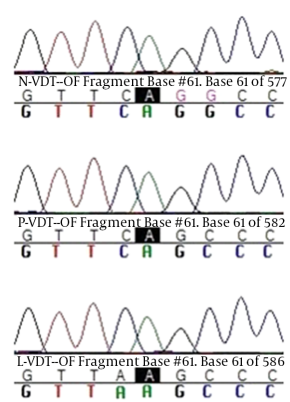

C
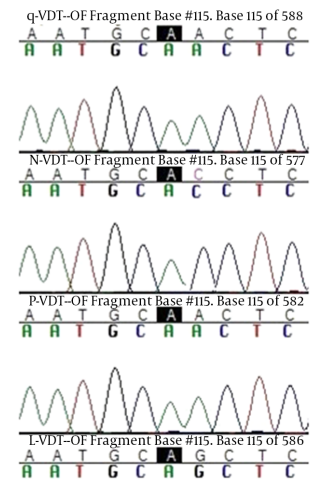

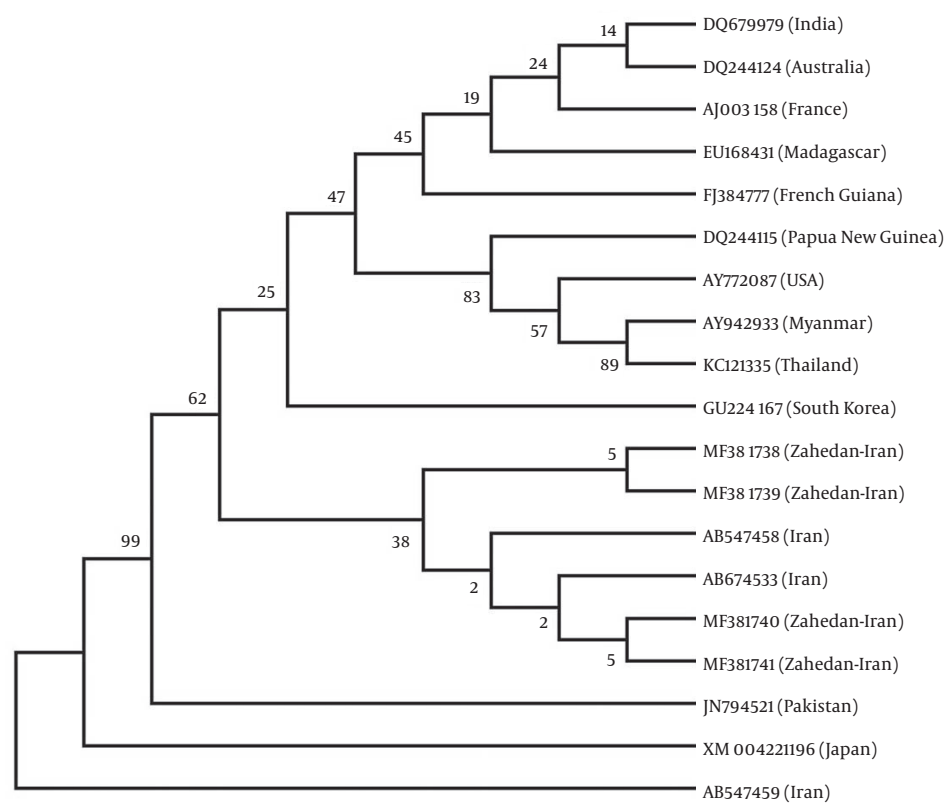

Figure 4. Bootstrap Neighbor-Joining Consensus Tree of Iranian pvdhfr Isolates Data Set by MEGA 6. Sequence of Zahedan Isolate is Shown in Clad of Recorded Previous Iranian Sequences

baijan (71\%) and Pakistan (93.5\%) $(26,27)$ was higher than that of the current study (32\%).

The haplotypes with one point mutation in locations $58 \mathrm{R}, 117 \mathrm{~N}$, and $117 \mathrm{~T}$ to form FRTS, FSTN, and FSTT were observed in this study, in which FSTN was the second frequent haplotype of $P$. vivax isolates in Iran (25). In comparison with the current survey, highly mutant alleles were reported from Thailand, Vanuatu, Indonesia, and Papua New Guinea. In line with previous studies, in this study haplotypes with double mutations at FRTN were also found in
Sistan and Baluchistan isolates, which was almost similar to that of obtained data from malarial endemic areas, such as Afghanistan and Pakistan $(16,25)$. Moreover, the distribution frequency of these haplotypes was not much different from previous studies (12). The present study did not find triple and quadruple mutations in any of the P. vivax isolates. In this regard, triple mutant haplotype has been reported in Afghanistan, which could be a warning for the arrival of these haplotypes to Iran from neighboring countries (25). However, due to the development of multi-drug 
resistance in P. falciparum, quadruple mutant alleles of $p v d$ $h f r$ at codons 57, 58, 61, and 117 were predominated in clinical isolates from India, Myanmar, Indonesia (28-30), and Thailand (31).

It appears that in these countries, diversity in the frequency of mutant pvdhfr alleles is a sign of drug pressure by usage of anti-folates. It has been reported that the $58 \mathrm{R} / 117 \mathrm{~N}$ mutant had a lower affinity for Pyrimethamine than the wild type enzyme (32), so that with an increase in the number of mutations, resistance to Pyrimethamine increases. Studies have shown that patients, whose parasites carried the allele of $57 \mathrm{~L} / 58 \mathrm{R} / 61 \mathrm{M} / 117 \mathrm{~T}$, were resistant to SP treatment $(28,33)$. Molecular analysis of the $p v d h f r$ gene in Indian isolates showed haplotypes from double to quadruple mutants. Therefore, it seems that these genotypes have entered Iran from India and Pakistan as gene flow of drug resistance, which may be due to human migration. With changing treatment pattern in Iran from 2005 , the SP became the first treatment option. Therefore, regarding greater availability of SP in endemic areas, such as Sistan and Baluchestan province, where P. vivax is still sensitive to $\mathrm{CQ}$, there is a risk of an altering pattern of resistance in both $P$. falciparum and $P$. vivax, due to SP drug pressure (20). Moreover, it has been suggested that in Iran, as an endemic area, other anti-folates, such as trimethoprim/sulfamethoxazole, which are usually used against bacterial infections, could enhance the drug pressure in malarious areas as well.

\subsection{Conclusions}

This study showed the presence of double $p v d h f r$ mutations in Sistan and Baluchestan province isolates. It presented important information to monitor the SP resistance in this region. Moreover, rising SP drug pressure suggested that the antifolate treatment against the P. falciparum malaria should be under control because it could affect the emergence of $p v d h f r$ mutations, which may lastly bring about a complete SP resistance in P. vivax species. Consequently, permanent surveillance of $P$. vivax molecular markers is necessitated to check the expansion of SP resistance.

\section{Acknowledgments}

This article is part of Mrs Maryam Rafee parasitology master's thesis with grant No. 7216 that is sponsored by Zahedan University of Medical Sciences in Infectious Diseases and Tropical Medicine Research Center and was performed in Zahedan University of Medical Sciences.

\section{Footnote}

Conflict of Interest Statement: The authors declared that they had no conflicts of interest.

\section{References}

1. Mendis K, Sina BJ, Marchesini P, Carter R. The neglected burden of Plasmodium vivax malaria. Am J Trop Med Hyg. 2001;64(1-2 Suppl):97106. doi: 10.4269/ajtmh.2001.64.97. [PubMed: 11425182].

2. Price RN, Tjitra E, Guerra CA, Yeung S, White NJ, Anstey NM. Vivax malaria: neglected and not benign. Am J Trop Med Hyg. 2007;77(6 Suppl):79-87. doi: 10.1186/s12936-015-0660-0. [PubMed: 18165478].

3. Mohammadzadeh T, Hatam G, Kalantari M, Sarkari B, Motazedian MH, Sadjjadi SM, et al. Molecular and microscopic-based characterization of plasmodium spp. in Fars and Hormozgan provinces, south of Iran.JTrop Med. 2014;2014:935469. doi:10.1155/2014/935469. [PubMed: 24799917].

4. Mirahmadi H, Fallahi S, Seyyed Tabaei SJ. Soluble recombinant merozoite surface antigen-142kDa of Plasmodium vivax: An improved diagnostic antigen for vivax malaria. J Microbiol Methods. 2016;123:44-50. doi: 10.1016/j.mimet.2016.02.003. [PubMed: 26851675].

5. Mirahmadi H, Spotin A, Fallahi S, Taghipour N, Turki H, Seyyed Tabaei SJ. Cloning and sequence analysis of recombinant plasmodium vivax merozoite surface protein 1 (PvMSP-142 kDa) in PTZ57R/T vector. Iran J Parasitol. 2015;10(2):197-205. [PubMed: 26246817].

6. Mirahmadi H, Fallahi S, Fallah Omrani V, Kazemi B, Haghighi A, Seyyed Tabaei SJ. High-level xpression of immunogenic recombinant plasmodium vivax merozoite surface protein (pvmsp-142 kDa) in pGEX 6P1 vector. Iran J Public Health. 2015;44(1):89-99. [PubMed: 26060780]

7. Shafiei R, Mahmoodzadeh A, Hajia M, Sanati A, Shafiei F. Epidemiology of malaria in khorasan razavi province, Northeast of Iran, within 7 years (April 2001 - March 2008). Ann Trop Med Public Health. 2011;4(1):12-7. doi: 10.4103/1755-6783.80515.

8. Zakeri S, Barjesteh H, Djadid ND. Merozoite surface protein-3alpha is a reliable marker for population genetic analysis of Plasmodium vivax. Malar J. 2006;5:53. doi: 10.1186/1475-2875-5-53. [PubMed: 16817951].

9. Pukrittayakamee S, Chantra A, Simpson JA, Vanijanonta S, Clemens $\mathrm{R}$, Looareesuwan $\mathrm{S}$, et al. Therapeutic responses to different antimalarial drugs in vivax malaria. Antimicrob Agents Chemother 2000;44(6):1680-5. doi: 10.1128/AAC.44.6.1680-1685.2000. [PubMed: 10817728].

10. Ratcliff A, Siswantoro H, Kenangalem E, Wuwung M, Brockman A, Edstein MD, et al. Therapeutic response of multidrug-resistant Plasmodium falciparum and P. vivax to chloroquine and sulfadoxinepyrimethamine in southern Papua, Indonesia. Trans R Soc Trop Med Hyg. 2007;101(4):351-9. doi: 10.1016/j.trstmh.2006.06.008. [PubMed: 17028048].

11. Alam MT, Bora H, Bharti PK, Saifi MA, Das MK, Dev V, et al. Similar trends of pyrimethamine resistance-associated mutations in Plasmodium vivax and P. falciparum. Antimicrob Agents Chemother. 2007;51(3):857-63. doi: 10.1128/AAC.01200-06. [PubMed: 17194833].

12. Zaman J, Shahbazi A, Asgharzadeh M. Plasmodium vivax dhfr mutations among isolates from malarious areas of Iran. Korean J Parasitol. 2011;49(2):125-31. doi: 10.3347/kjp.2011.49.2.125. [PubMed: 21738267].

13. Baird JK. Resistance to therapies for infection by Plasmodium vivax. Clin Microbiol Rev. 2009;22(3):508-34. doi: 10.1128/CMR.00008-09. [PubMed: 19597012].

14. Kurcer MA, Simsek Z, Zeyrek FY, Atay S, Celik H, Kat I, et al. Efficacy of chloroquine in the treatment of Plasmodium vivax malaria in Turkey. Ann Trop Med Parasitol. 2004;98(5):447-51. doi: 10.1179/000349804225021343. [PubMed: 15257793].

15. Soto J, Toledo J, Gutierrez P, Luzz M, Llinas N, Cedeno N, et al. Plasmodium vivax clinically resistant to chloroquine in Colombia. Am J Trop Med Hyg. 2001;65(2):90-3. doi: 10.4269/ajtmh.2001.65.90. [PubMed: 11508397]. 
16. Zakeri S, Motmaen SR, Afsharpad M, Djadid ND. Molecular characterization of antifolates resistance-associated genes, (dhfr and dhps) in Plasmodium vivax isolates from the Middle East. Malar J. 2009;8:20 doi: 10.1186/1475-2875-8-20. [PubMed: 19175936].

17. Zakeri S, Najafabadi ST, Zare A, Djadid ND. Detection of malaria parasites by nested PCR in south-eastern, Iran: evidence of highly mixed infections in Chahbahar district. Malar J. 2002;1:2. doi: 10.1186/14752875-1-2. [PubMed:12057020].

18. Zakeri S, Gil JP, Bereckzy S, Djadid ND, Bjorkman A. High prevalence of double Plasmodium falciparum dhfr mutations at codons 108 and 59 in the Sistan-Baluchistan province, Iran. J Infect Dis. 2003;187(11):18289. doi: 10.1086/375250. [PubMed: 12751044].

19. Sirawaraporn W, Prapunwattana P, Sirawaraporn R, Yuthavong Y, Santi DV. The dihydrofolate reductase domain of Plasmodium falciparum thymidylate synthase-dihydrofolate reductase. Gene synthesis, expression, and anti-folate-resistant mutants. J Biol Chem. 1993;268(29):21637-44. [PubMed: 8408015].

20. Barnadas C, Tichit M, Bouchier C, Ratsimbasoa A, Randrianasolo L, Raherinjafy R, et al. Plasmodium vivax dhfr and dhps mutations in isolates from Madagascar and therapeutic response to sulphadoxine-pyrimethamine. Malar J. 2008;7:35. doi: 10.1186/14752875-7-35. [PubMed: 18302746].

21. Hawkins VN, Joshi H, Rungsihirunrat K, Na-Bangchang K, Sibley CH. Antifolates can have a role in the treatment of Plasmodium vivax. Trends Parasitol. 2007;23(5):213-22. doi: 10.1016/j.pt.2007.03.002. [PubMed: 17368986].

22. Sharifi-Sarasiabi K, Haghighi A, Kazemi B, Taghipour N, Mojarad EN, Gachkar L. Molecular surveillance of Plasmodium vivax and Plasmodium falciparum dhfr mutations in isolates from southern Iran. Rev Inst Med Trop Sao Paulo. 2016;58:16. doi: 10.1590/S1678-9946201658016. [PubMed: 27007559].

23. Nateghpour M, Sayedzadeh SA, Edrissian GH, Raeisi A, Jahantigh A, Motevalli-Haghi A, et al. Evaluation of sensitivity of Plasmodium vivax to chloroquine. Iranian J Publ Health. 2007;36:60-3.

24. Huang F, Zhou S, Zhang S, Li W, Zhang H. Monitoring resistance of Plasmdium vivax: point mutations in dihydrofolate reductase gene in isolates from Central China. Parasit Vectors. 2011;4:80. doi: 10.1186/1756-3305-4-80. [PubMed: 21586132].

25. Zakeri S, Afsharpad M, Ghasemi F, Raeisi A, Safi N, Butt W, et al. Molecular surveillance of Plasmodium vivax dhfr and dhps mutations in iso- lates from Afghanistan. Malar J. 2010;9:75. doi: 10.1186/1475-2875-9-75. [PubMed: 20226087].

26. Khatoon L, Baliraine FN, Bonizzoni M, Malik SA, Yan G. Prevalence of antimalarial drug resistance mutations in Plasmodium vivax and $\mathrm{P}$. falciparum from a malaria-endemic area of Pakistan. Am J Trop Med Hyg. 2009;81(3):525-8. [PubMed: 19706926].

27. Brega S, de Monbrison F, Severini C, Udomsangpetch R, Sutanto I, Ruckert P, et al. Real-time PCR for dihydrofolate reductase gene single-nucleotide polymorphisms in Plasmodium vivax isolates. Antimicrob Agents Chemother. 2004;48(7):2581-7. doi: 10.1128/AAC.48.7.2581-2587.2004. [PubMed:15215112].

28. Hastings MD, Porter KM, Maguire JD, Susanti I, Kania W, Bangs MJ, et al. Dihydrofolate reductase mutations in Plasmodium vivax from Indonesia and therapeutic response to sulfadoxine plus pyrimethamine. J Infect Dis. 2004;189(4):744-50. doi: 10.1086/381397. [PubMed: 14767830].

29. Imwong M, Pukrittakayamee S, Looareesuwan S, Pasvol G, Poirreiz J, White NJ, et al. Association of genetic mutations in Plasmodium vivax dhfr with resistance to sulfadoxine-pyrimethamine: geographical and clinical correlates. Antimicrob Agents Chemother. 2001;45(11):31227. doi: 10.1128/AAC.45.11.3122-3127.2001. [PubMed: 11600366].

30. Na BK, Lee HW, Moon SU, In TS, Lin K, Maung M, et al. Genetic variations of the dihydrofolate reductase gene of Plasmodium vivax in Mandalay Division, Myanmar. Parasitol Res. 2005;96(5):321-5. doi: 10.1007/s00436-005-1364-0. [PubMed: 15924223].

31. Rungsihirunrat K, Na-Bangchang K, Hawkins VN, Mungthin M, Sibley $\mathrm{CH}$. Sensitivity to antifolates and genetic analysis of Plasmodium vivax isolates from Thailand. Am J Trop Med Hyg. 2007;76(6):1057-65. [PubMed: 17556611].

32. Tahar R, de Pecoulas PE, Basco LK, Chiadmi M, Mazabraud A. Kinetic properties of dihydrofolate reductase from wild-type and mutant Plasmodium vivax expressed in Escherichia coli. Mol Biochem Parasitol. 2001;113(2):241-9. doi: 10.1016/S0166-6851(01)00230-4. [PubMed: 11295178].

33. de Pecoulas PE, Tahar R, Ouatas T, Mazabraud A, Basco LK. Sequence variations in the Plasmodium vivax dihydrofolate reductase-thymidylate synthase gene and their relationship with pyrimethamine resistance. Mol Biochem Parasitol. 1998;92(2):265-73. doi: 10.1016/S0166-6851(97)00247-8. [PubMed: 9657331]. 